\title{
Review
}

\section{The exigence of the common logistics policy for European community and the deconstruction of the common transportation policy}

\author{
M. Hakan KESKIN \\ University of Turkish Aeronautical Association, Faculty of Business Administration, Ankara, TURKEY. E-mail: \\ mhkeskin@yahoo.com. Tel: + 9031234284 58. Fax: + 903123428460.
}

Accepted 12 October, 2012

\begin{abstract}
Common transportation policy (CTP) is among the oldest policies of the European Union (EU) ${ }^{\mathrm{i}}$. Although, no common logistic policy has been introduced so far, it is ironic, because transportation is one of the main constituents of logistics which is regarded as the millennium's rising value. This does not mean that the European community does not care about logistics. Many companies, located in Europe, have conducted many comprehensive, sophisticated and developed logistic activities. The EU ports, which ranked at the highest levels in the world, recently leave their positions to the Asian ports. Besides that, traffic jams in main arterial highways, chronic delays in airways also force the European countries to move in coordination. The community can neither solve the existing mainly economic and fiscal problems nor be successful in any of the existing common policies without developing efficient logistic polices. The EU cannot be successful in the global competitive race, without common logistics strategies, as well. The requirement for common logistic policy has become more definite and imperative. The EU should transform its common transport policy to common logistics policy without any delay since this is the only way out for the EU.
\end{abstract}

Key words: Common logistics policy, logistics, transportation, common transport policy, outsourcing.

\section{INTRODUCTION}

The EU has started to develop a series of common policies just after its foundation on the legal base of primary legislation. The common policies are to be in line with the mutual interests of the members and produced as needed to meet the major challenges, in order to take scale advantage. As of 2012, the number of common policies reached $35^{1}$. The creation of single market ${ }^{2}$ was prior in the early years of the Community. Instead of being obstructed by national borders and barriers, people, goods, services and money should move around the EU as freely as they do within a single country. The community decision makers focused on transportation

\footnotetext{
${ }^{1}$ But due to the hesitation of the member countries in transferring law-making authority to the EU, expected outcome didn't come. Look for details: The EU Policy Areas, (http://the Europa. The EU/pol/index_en.htm).

${ }^{2}$ Sometimes also is called the 'internal market'. (Border-free Europe (single market, http://europa.eu/pol/singl/index_en.htm).
}

issue and launched the CTP to make Europe's transport systems more efficient.

Although, logistics was thrown backwards, the EU has not produced a common policy to deal with logistic purely. In other words, there is no common logistics policy.

Logistic sector is accepted as the rising value of the millennium and comprises a wide field including transportation (Stock and Douglas, 2001). However, according to a survey in literature, it is determined that the studies on the EU logistic activities are rare. This study, as different from the others, focuses mainly on logistic policies of the EU, while trying to analyze the CTP.

\section{Logistics concept according to the community}

Before the analysis of the EU's logistic sector, it can be useful to have a look at what the logistics signifies for the 
EU. The survey of logistic studies which has increased in number in the last decades shows that it will be difficult to reach any sort of consensus on content of logistics (look at the details about logistic in literature by Bowersox and Closs (1996), Ghiani et al. (2004), Ballou (2004) Murphy and Wood (2004)). Rather than giving all of the definitions of logistics in literature, it should be better to determine how logistics is defined and what its contents are, according to the community.

A logistics report, prepared by the Commission, in 2006, which is the first of few EU documents on logistics, can be helpful in this study (Commission, 2006c). In this report, the Commission uses the term of the freight logistics, which is rarely encountered in logistics literature and can be defined, as the planning of freightage operation, the organization, the administration, the control and effectuation in the supply chain. The main constituents of logistics were limited with production by the Commission and include:

1. All of the freight and transit transports, storage activities, orders and the services directly related with production and retail activities.

2. All of the value-added inventory maintenance services. 3. Plans and administration of supply chains during transition process, ordering process within actions related to administration activities.

Logistics, in the Commission sight, is an industry that has constantly developed. The Commission approaches the logistics as a matter of economy and considers it as a crucial element that enhances economic growth. Besides that, logistics, if managed effectively, contributes to cope with some challenges such as traffic jams, energy supply, security problems and high unemployment rates. The Commission also notes that logistics can reduce the harmful effects of the freight transportation to the environment.

The second paper of the EU about logistics is a report (Meyer-Rühle et al., 2008) penned by a group that is composed by 12 researchers among private entrepreneurs for the Directory of Transportation and Energy of the Commission in 2008. Figure 1 gives a clear meaning of logistics and the bond between transport and logistics, according to the EU (Meyer-Rühle et al., 2008). It is interesting that Meyer-Rühle and his friends' attitude to logistics was limited with out-sourcing, while the production and distribution processes are excluded from the logistic scope.

\section{Arrangements by the Community in logistics}

CTP was initiated in 1957 and is one of the oldest common policies, however, the EU's first concrete step of the community in logistics was a communication (Commission, 2007a) released by the Commission which include some suggestions in order to cope with the logistics challenges of the Community in 2006. Logistics action plan, (Commission, 2007b) took place in 2007 as the second step of the Commission under the name of precaution package.

The logistics action plan is to help industry move towards a more efficient use of freight transport, mitigating the factors that are driving up prices in the logistics industry and jeopardizing the sustainability of its practices. The commission put forward some medium term logistic policy aims to focus on, such as freight transportation, education, quality indicator, simplification of the processes, extent of vehicle and freight, local shipping and long distance corridors in the action plan. Parallel to these initiatives, The Commission called the sectors' stakeholders for further action to overcome the congestion that is denoted as bottleneck in practice (Commission, 2007a). Not having any logistics initiative until 2006 (and being limited only with shipping policy after 2007), is a significant deficiency for the EU decision makers while logistic sector has been growing so fast. While the first significant progress of CTP took place just after creation of the community, the EU waited 20 years for logistics. Figure 1 presents what the EU has done up to now by in logistics and transportation comparatively. It is so clear that the EU has done almost nothing by means of logistics.

\section{THE POTENTIAL OF THE EU LOGISTICS AND THE DYNAMICS OF THE EU LOGISTICS MARKET}

It is not easy to monitor the EU logistics market as a whole, because the statistical data regarding the EU logistics market is not sufficient. Data, given by The Eurostat, the statistical office of the EU, is limited with transportation sector and generally about the number of ship, plane, automobile, truck or train, the lengths of paths, the amounts of carried cargo and number of passenger. In the documents which are released or to be prepared by the Commission, it is not possible to find any trust-worthy data to be referred to other areas of the logistics except transportation in the EU literature. Beside all these, the limited available data regarding to the logistics is out of date.

EU member states take their place in the ranking of the logistics performance index $(\mathrm{LPI})^{3}$ in the latest edition of this report published in 2012 (Arvis et al., 2012). Moreover, it is remarkable that all of these countries are

\footnotetext{
${ }^{3}$ In this report "Logistic Performance Index "terms eliging of English is LPI and it mentioned about stage of logistic performance. The low level it means that the worst performance in LPI-1 than maximum level means that the better performance in LPI-5 till it has got 5 different logistic performances and it is draw attention to multidimensional feature. By from 2012130 countries confirm about time, cost, export and import security chain, quality of infrastructure, main service performance and it defined factors of use commerce procedure.
} 


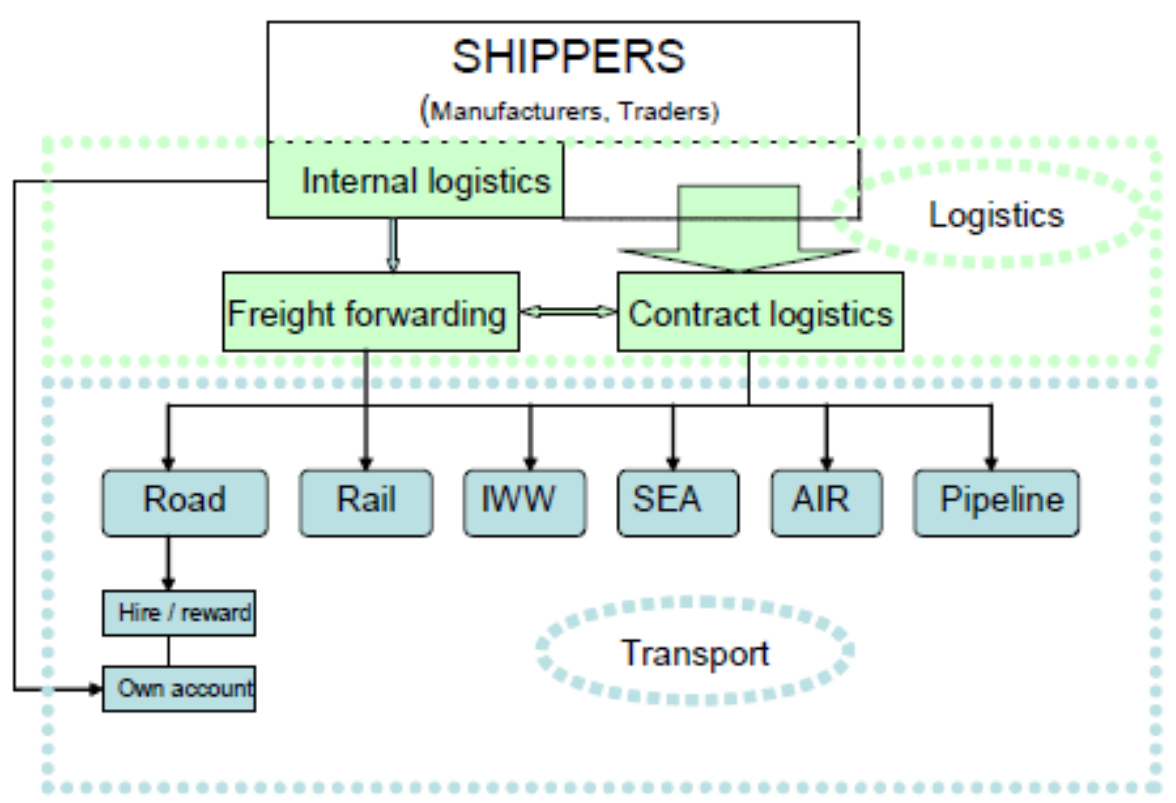

Figure 1. EU's logistics and the scope and relation of transport sector. Source: Olaf et al. (2008). Statistical Coverage and Economic Analysis of the Logistics Sector in the EU (SEALS) Final Report Prepared for the European Commission, DG Energy and Transport, ProgTrans AG: SEALS-Final Report, December 2008, p.6.

members of the community (Finland $3^{\text {rd }}$, Germany $4^{\text {th }}$, Holland $5^{\text {th }}$, Denmark $6^{\text {th }}$, Belgium $7^{\text {th }}$ and United Kingdom $10^{\text {th }}$ ).

Global developments of the millennium increase the importance of the logistics sector also for the EU. According to the figures given by the Commission in the official website of the EU, one-third of 750 million vehicles are used by the drivers of the EU. The largest ship fleet of the world is in Europe (EU and EEA). Every year approximately 80.000 merchant ships come to shores of Europe. The logistics sector in the community constitutes $15 \%$ of the cost in finished products. According to the Commission (2011b), failures in logistics channels cost $1 \%$ of Europe's GDP. While the aviation sector in Europe makes it possible to employ approximately 3.2 million people directly and indirectly, 670 thousand people merely work in airports and airlines (Commission, 2010c).

According to the Commission (2006c), the importance of the logistics increases not only for the internal market of Europe but also for its international business relations. Top 20 outsourcing companies (Murphy and Wood 2004) in Europe having only 33\% shares of the market shows fierce competition in the European logistics sector. In the eye of the Commission, globalization of the production and, in return, increasing volume of the supply chain raises the need for transportation. The logistics becomes gradually an important factor in the competition of the EU with the US and the Far East. The Commission has been negotiating for the integration of the market and business world of Europe with the logistics centers such as US,
China, Russia, Japan, India and Brazil and the integration of other international actors into the transportation markets at bilateral or multilateral level for a long time.

\section{Current trends in the EU logistics market}

Meyer-Rühle et al. (2008) have categorized the efficient factors in shaping the EU logistics market and currently developing trends depending on these factors as follows:

1. Globalization of trade and production; gradually increasing globalization results in boosting hauls, creating new needs for the communication and integration and increasing competitive pressure.

2. Transition to post-industrial society; coming to the end of the boost in the industrial production in the Western Europe brings about individualization in production and demand for more services.

3. Increasing sensitivity of the demand-side economies against time; despite the pressure of producing and performing service in line with the customers' demand, the industrial approaches based on stock give their places to the philosophy of JIT.

4. Increasing external risks and environment pressure; increasing effects of global terror and widening its scope and the risks resulted from increasing emission depending on the energy consumption bring about acting in line with the security-centered way. Sustainability in the logistics chains starts to become prominent. 
5. Rediscovering effects of the optimized structures and processes; it is started to be used for creating valueoriented processes and pull-based supply chains.

6. High technology creating new opportunities to increase quality and to decrease costs; increase in internet use and getting easy of tracking product flow enable Internet to be developed with a new initiative.

7. Traditional public transportation and communication companies giving their places to hybrid logistics service providers with the acceleration of the privatization processes; todays actors in the logistics sector are different compared to the former ones who had generally public identities. Beside this, the actors such as airliners, logistics villages, which have government support, have devastated the competition.

8. Value sharing turning into one of the factors of the management success; the rate of outsource gradually increases since renewed financial motives require attention to actual work.

\section{Outsourcing in the EU}

One of the main areas, where European countries are prominent, is the performances of the third party logistics firms (www.eyefortransport.com, 2012). While Deutsche Post World Net (DPWN), one of the leader logistics outsourcing businesses on the global level, is a leader not only in Europe but also in the postal and bank services all over the world with its capital exceeding 33.4 billion Euro, Schenker comprises of two main groups: The European Land Transportation (ELT) and Air and Sea Freight (ASF) is a giant in air and land transport on the global level. Panalpina, another outsourcing firm based in Europe, carries out outsource operations with the leading businesses having high technology and being specialized in the transportation of health care, automotive and oil products such as Delphi Corporation, Bosch Group, ST Microelectronics. Exel, ranking fourth among outsourcing businesses with its contract volume of 2.4 billion Euros, acquires approximately $40 \%$ of its revenue from the sectors of automotive, chemical, consumption, health care, industrial, retail and IT in Europe. Kuehne and Nagel, a global business in the area of sea and air transport, outsources especially for Germany, the UK, Sweden and other Scandinavia countries.

It can be said that one of the reasons of rapid development in the European outsource sector is the market trend which turns its face from national to Europa as a result of the common market's functioning. Another reason is the increasing trend in the areas of mergers and their alliances, which rise price transparency and create synergy in Europe with the transition to Euro. Despite all these positive factors, the Euro zone, falling into a crisis especially in the countries such as Greece, Ireland and Portugal with the global financial crisis and the damping effect caused by rapidly developing markets in Asia, dominated by China, is seen as a threatening factor for the outsource market.

The outsourcing businesses in Europe search for opportunities to boost their business volumes. The businesses are forced into enhancing their performances in the logistic chain by concentrating on core competences since challenging competition in Europe requires using outsource and operating in the global chains.

There are some main problems encountered in the outsource market and specific factors limiting outsource in Europe although the logistics market grows. It can be said that these factors are the difficulty of service quality, the difficulty of the control of this quality and performing service at the lowest price being still the most important motive to prefer (www.eyefortransport.com, 2012).

In recent years, it has started to be seen that logistics organizations focus on the European markets. But they have to cope with traffic. The traffic in Europe, increasing excessively on the main arterial roads, which provide the direct transport from the storages to customers, forces the businesses to establish the regional distribution centers. Besides that there is a significant increase in tendency towards carriers buying outsource service from the outsource providers (Commission, 2006c).

It has been seen that the outsource contracts in Europe are concluded to establish much longer and extensive cooperation. The European businesses, which try to optimize the supply chain, have started to revise the alternatives on the issue of load transport. For example, the large volume carriers have started to integrate the transport mode. It can be said that the global trends whose importance increases such as environmental effects of the energy consumption. The dynamics of the businesses' locations are other efficient factors in shaping the sector (Commission, 2006c).

\section{Transport market dynamics of the Europe and CTP}

According to the European Commission (Commission, $2010 \mathrm{~b}$ ), transport sector making the rate of 500 billion Euros based on a basic price, corresponds to (as of the EU-27/2007) 4.6 of total incomes including storing, stocking and other supportive activities. The number of workers in transport sector constitutes $4.5 \%$ of sector's total employment (9.2 million people). Among those employees, $63 \%$ is employed in land, $2 \%$ in sea and $30 \%$ in support services. In 2008 the EU citizens spent 945 billion Euros for transportation need. This rate equals to $13.4 \%$ of general expenditure total. Transport sector constitutes $4.6 \%$ of the EU's all GDP. According to the Commission, the equipment used in transport sector gives additional support to the mentioned rates as $1.7 \%$ of GDP, $1.5 \%$ of employment (The EU web site, $2012 b$ ). $40 \%$ of transport sector investments is made by member state governments. $30 \%$ of power consumed in the EU 
pertains to transport sector. Until 2020, transport sector is anticipated to grow $1.6 \%$ each year. Community has allocated huge amount ${ }^{4}$ for transport sector that TENs' budget is 390 billion Euros between 2007 and 2013 only (http://www.civitas.org, 2012).

According to the Commission, the success of transport policies will contribute especially to free circulation and the success of common market and it will facilitate the works of people who want to travel in Europe. By this means, living standards will rise. The Commission also warns the member states for security problems and lowcost and common transportation brought with easy transportation will damage transport sector of developed countries besides the advantages of transportation policy.

\section{THE DEVELOPMENT OF COMMON TRANSPORTATION POLICY}

CTP is, one of the earliest policies, recommended ${ }^{5}$ in the Treaty of Rome (Treaties, 1957, 1992), which is the founding treaty of the EU. In Article 74, transportation issue is indicated as one of the main objectives of Community, and member states are invited to constitute a CTP (Kuşçu, 2011).

However there has not been any remarkable progress due to member states' avoiding to delegate their authorities to Community. In 1983, there happened a shift: The EU Parliament sued the Council of Ministers to the European Court of Justice on the account of not meeting the requirements of the treaty (Gleave, 2009).

Another trigger for improving transportation policy was the signing of Single European Act (SEA) in 1986, which includes provisions to form the Common Market ${ }^{6}$. The SEA made the article 75 of Treaty of Maastricht and Rome changed ${ }^{7}$. After that political, institutional and financial aspect of CTP has been reinforced. 1990 started within this environment. It became easier for service providers to pass through member states' borders than before.

\footnotetext{
${ }^{4}$ The EU's 2012 budget is approximately 140 billion Euros annually.

${ }^{5}$ Transportation is organized in Treaty of Rome for the other title (between the article 71-article 84). Institutions on the Communities want to define that the article 75 in the treaty about starting the member states or international transmit activities when they pass in transit are applicable joint rules and it want to define also member states have not got transmit conditions. The other articles general mentioned about decrease of freightage and organized about definite transmit conditions, for example they avoid the discrimination, also these articles mentioned about the treaty involves in railway and inland waterway. Look at for the details: The Treaty of Rome, Title IV Transport, 25 March 1957.

${ }^{6}$ The Single European Act Section II emphasis for article 13 freedom movement in the Internal Market and also it refers to Rome Treaty in article 84. ${ }^{7}$ Maastricht Treaty change article in 75 is briefly; consideration of article 74 about transmit sector refers to article $189 \mathrm{c}$ and then consult of the economy and social committee; and it add to Rome Treaty security aims. Also its stipulate obstacle any restriction for important to employment and life conditions. Also this article emphasis of joint market. (Treaty on the EU (Treaty on Maastricht) Official Journal OJ C 191 of 29.7.1992.)
}

The Community published some basic policy documents with the purpose of attaining the goals of common transport policies. First of them was, White Paper, (Commission, 1992) published in 1992, which emphasized the integration of the EU transport market. Eight years later, in 2001, the Community published the second White Paper (Commission, 2001) which affirmed the balance between transportation modes, elimination of traffic congestions and placing the people, who utilize the transportation services at the center of transportation policy. With the enlargement of 2004, new objectives are set such as developing transportation substructure of new members and linking with the west of The Europe (Šakalys, 2006). In the meantime the realization of TENs projects have been deferred.

In 2006, Commission published the midterm assessment (Commission, 2006d) of white paper which focuses on the issues of global warming and the increase of energy prices ensued with globalization in addition to the security and terror problems brought along the EU enlargement called as sustainable mobility in Europe (Wolf, 2006). Within this document, sustainable development strategy which was adopted in 2001 and renewed sustainable development strategy which was adopted in 2006, are added to the objectives of transportation policies. Also long-term transportation scripts of 20 and 40 years are sought to be prepared by the Commission.

The Commission published the last White Paper about 25 policies in 2011. Some solutions are proposed in this paper to cope with current problems such as elimination of dependence on fossil fuel, use of railways more instead of road as a means of travel, making $40 \%$ of aviation fuels as low carbon emission.

Schmidt and Giorgi (2001) spoke of three phases in the development of the CTP as period between 1957 and 1985; the period between 1985 and 1991; and the period since 1992. Considering they conducted their study in 1991, we have modified the phases and categorized CTP under four basic phases;

1. First phase 1957 to 1985 (formation phase).

2. Second phase 1985 to 1991 (the White Paper which is completing the internal market and the signing of the Single European Act).

4. Third phase 1992 to 2004 (after enlargement).

5. Fourth phase 2004 to 2012 (contemporary period).

As a result, it is seen that the common transportation policy took its present form with documents ${ }^{8}$ determining Community policies published the first in 2001 and the

\footnotetext{
${ }^{8} 2001$ White Paper: European Transport Policy for 2010: Time to Decide; 2006 White Paper: Keep the Europe moving; 2007 White Paper: Keeping freight moving; 2008 White Paper: Greening transport; 2009 White Paper: Maritime Transport; 2009 White Paper: Future of Transport; 2011 White Paper: Roadmap to a Single European Transport Area - Towards a competitive and resource efficient transport system.
} 
last in 2011. The EU decision makers have valued transportation more careful each passing year.

\section{CURRENT VIEW OF COMMON TRANSPORT POLICIES}

The main objectives of last transport policy which was declared by the Commission to be applied in the first decades of millennium are the producing solutions of freight transport and active travel for passengers and employers and making the EU transport system more sustainable for the EU (The EU web site, 2012f).

In other words, the objective of the current CTP is supporting the EU internal market and providing a neat, secure and effective transportation of goods and persons across the EU. For the former version outdated as of 2010 , attempts to develop a new one have been going on. The new version of the CTP should consider some dynamics as ageing issue, migration effect, environment problems, shortage of fossil fuel, urbanization acceleration and other global tendencies. Issues such as; rendering the transportation substructure in an integrated system, reinforcing each transportation mode, organizing the competition and single market while using multitransportation modes, prioritizing security and safety, considering the working conditions of transportation sector, forming an explicit clear and coherent legal basis, generating solutions including all parties and coordinated with member states transportation policies should be included in the scope of the new CTP. The success of CTP is the foremost factor of the economic integration of the Community, which has gone through a phase of using single currency.

If CTP were not among the successful common policies, single market would not be realized by all means.

\section{THE DYNAMICS OF THE TRANSPORT SECTOR ACCORDING TO THE MODES IN THE EU}

The Community tries to establish a balance between transport modes (Koldemir et al., 2007). Road is in the first place with $45.9 \%$ among all others. Maritime is in the second place with $36.6 \%$, while rail is in the third with $10.8 \%$.

\section{Road transport}

The aim of the EU's road transport policy is to promote an efficient, mobile, secure and environment friendly road transport. The EU works on some principals such as enhancing service quality in freight transport and personnel transport, creating a suitable environment for competition in the sector, determining safer and more environment friendly standards, ensuring fiscal and social harmonization of the sector which differentiates according to the member countries, making legal arrangements to be applied without discrimination for being successful (http://ec.the Europa, 2012f). Within this framework the EU laws set standards for conditions of using tachograph, tolls for heavy goods vehicles, working conditions such as driving time and rest periods of the drivers and minimum annual vehicle taxes which need to be complied by the member states.

\section{Rail transport}

The EU Commission, which has been working on the issue of restructuring the European railway market and strengthening the share of the rail transport vis-a-vis other transport modes in the last two decades, concentrates on three major aims, such as opening of the rail transport market to competition, improving interoperability and safety of national networks and developing rail transport infrastructure (Solecka, 2011). The EU Commission regards cross border opening of national freight and personnel transport to competition as one of the major steps of creating an integrated the European railway area and the EU internal market for rail. The EU legal arrangements based on the distinction between the companies working in the area of infrastructure and the companies responsible for the business aim to promote greater competition in the rail transport sector since its formation in 1991. Any licensed EU railway company can offer shipping services by rail throughout the EU. Personnel transport service has been completely liberalized as of 1 January, 2010. However, it cannot be said that any railway company is, in practice, able to offer services in the country which it wants. In the report published by the Commission in 2009, it is stated that the countries, which have mostly failed in the rail transport, are Spain, France, Luxembourg, Greece and Slovenia (Commission, 2009e).

\section{Air transport}

The airline sector is prominent among other sectors contributing to The Europe GDP with registered airlines over 130, airports over 450 and 60 air traffic service authorities with its 120 billion Euros (The EU web site, $2012 \mathrm{~g}$ ). The aim of the EU in the area of air transport is to control the growth in air transport, to find a solution for concentration in the sky, to protect the environment and to establish and sustain security standards. All administrative barriers in flights within the EU have been removed (thanks to the initiatives to create single aviation market starting after 1990s). The air transport based on high technology differentiates from other transport modes with its one aspect in national airports are used rather by national airlines of the member countries. The EU airline 
businesses can freely use all flight corridors within the EU by the nature of the single market. The policy of the EU for the single aviation market, which is established with the directive, dated 2008 and has specific aims (Commission, 2008a) such as more active and recent route and airport, more options and less money and higher service quality, aims to create competition and to prioritize security. The Single European Sky (SES) is an initiative since 2004 which was intended to reform the European air traffic control for meeting the needs and the capacity of the EU in the future. It is expected that air traffic density, which declines after 9/11 attacks all over the world, increases $4 \%$ in the next 15 years and is expected to double in 2020 in the Europe. The lack of security and insufficient capacity are still major problems to handle. The EU and its members should take into account some dynamics such as environment, fuel prices and cost effectiveness from now on. To cope with these challenges, the Community has initiated the Galileo Project (EP and Council, 2008b) which aims to arrange the European air traffic control and navigation system on the European level, and implemented another initiative, SES, since 2004. Further, legal arrangements are renewed upon the demands from the member countries and the actors in the sector and as third attempt, SES II has been launched (Commission, 2010a).

\section{Maritime transport in the EU}

Maritime is an important factor for The Europe's economic development and welfare throughout the history. Every year passengers over 400 million travel by using The European ports. Business corporations prefer maritime transport rather than road transport. The maritime transport is the most preferred transport mode with the rate of almost $90 \%$ in trade among the European countries and in their trades with outside world in the areas of food, merchandise and especially energy. Moreover, the maritime transport is of vital importance for the residents of the island countries and the countries surrounded by sea (Paixaäo and Marlow, 2001). Furthermore, the maritime industry makes a significant contribution to The European economy in terms of employment and direct income. In the maritime transport sector, which has these dynamics, the Commission implements a more sensitive maritime policy to environment, which includes strict rules preventing substandard shipping and measures taken to prevent maritime disasters. Addition-ally, the Commission fights with terrorist threat and pirate activities (Dekker and Stevens, 2007). By doing so, the Commission carries out works on the issues of improving working conditions, coping with security and safety problems in maritime sector (Commission, 2007e), sustaining professional qualities of sailors and government support to ports. Protecting the rights of the EU citizens, who use maritime service within the scope of the EU, maritime transport policy adopted by the EU most recently, focuses on being sufficient of the public service provided by the member countries (Farantouris, 2012). In the Commission Document, (The EU web site, 2012d) in which maritime transport strategy adopted in January 2009 and categorized under six chapters, two major aims are stated to be achieved by 2018 (Commission, 2009d).

1. Making maritime transport sector meet the needs of the sustainable economic growth in the EU and the world and provide cost-effective services,

2. Opening up long-term competition by strengthening directly or indirectly the EU's employment and capacity to create value in the EU maritime sector.

The EU, which has ports over 1000 handling annually 3.5 billion tons of cargo, has a large internal market for maritime. Whereas 700 of 1000 ports have a capacity to handle under 1 million tons, only 10 ports have a capacity to handle over 50 million tons in Europe. Europe creates approximately a value of 111 billion Euros in maritime space (Amerini, 2010). Commercial ports over 1,200 located on the shores of The Europe within $100 \mathrm{~km}$ host $90 \%$ of the international trade of Europe. Therefore, the Commission always makes action plans for the development of the EU ports. It can be said that almost 3.4 billion tons handled in 2009 being equal to the tons handled in 2003 is one of the signs indicating the EU's financial difficulties on the global level. The liquid bulk freight (including oil products) handled in 2009 comprises $42 \%$ of the total cargo handled in the EU-27 countries. This is respectively followed by the dry bulk freight with $23 \%$ and the container transport with $18 \%$. In the North Sea Rotterdam, Antwerp and Hamburg ports are the top three in The Europe by their functions. The reason of no decrease in the number of passengers, which is approximately 403, carried from the EU-27 ports in 2009 contrary to freight transport, is that maritime transport is the most preferred mode in the member countries of the EU. However, it is not possible to say the same thing for the number of ships coming into ports. There was a $5 \%$ decrease in the number of ships coming into ports in 2009 compared to the previous year. Similarly, there was a $3 \%$ decrease in the rate of freight. While the decrease in freight transport is $12.4 \%$ on the EU level, most decreased freight transport is $(-28.5 \%)$ in Romania on the country level. It is followed by Slovenia and Finland. It is remarkable that there is an increase only in Estonia $(6.4 \%)$ and Malta on the country level. Although the UK has experienced constant decrease since 2005, it is the leader among the EU-27 with 501 million tons handled. This figure comprises $15 \%$ of the EU-27. The UK is respectively followed by Italy with $14 \%$ and the Netherlands. For the first time, agricultural products draw attention in 2009 by enabling with $64 \%$ increase in the export transport (Commission, 2009a). 


\section{Inland waterway transport}

Inland waterway transport has developed by $17 \%$ in the last 30 years and has a vital role in the transport of goods in Europe, which has waterways over $37.000 \mathrm{~km}$ connecting industrial regions to cities. 20 out of $27 \mathrm{EU}$ members use inland waterway for transport and 12 out of this 20 country are significantly efficient. The EU intensively works in order to boost competition and to incorporate inland waterway transport mode into the logistics chain in inland waterway transport, which has no disadvantages such as congestion of traffic and capacity but has some advantages such as being safe and environment friendly. The main reason of the Commission giving such an importance to inland waterway transport, which is a competitor of rail and road transport, is that the Commission aspire to achieve saving in energy consumption and aims for decreasing air and noise pollution. According to the data in the website of the EU, (http://ec.europa, $2012 \mathrm{~m}$ ) energy consumption in inland waterway transport per $\mathrm{km} / \mathrm{ton}$ is $17 \%$ less than road transport and $50 \%$ less than rail transport. Moreover, the Community aims for more businesses performing service in the market for inland waterway transport which has septuplet less risk of accident and results in less noise and air pollution than road transport. Naiades Action Program (Commission, 2007d) supported by Platina, a main trans-the European Project put in action on 1 October, 2008, to be applied between 2006 to 2013.

\section{OTHER INITIATIVES OF THE EU TRANSPORT POLICIES}

In order to increase the effectiveness of European transport sector of the Community, a number of initiatives that will contribute to the achievement of the goals of the common transport policies has been developed for EU's transport policy.

\section{Combined transportation in the EU (Marco Polo program)}

The Commission's Marco Polo program which was intended to be applied between 2003 to 2006 (The EU web site, 2012n) and in which more than 500 enterprises were involved for 125 projects, is the most comprehensive program that the EU carries out in the field of multi modal transport. 3 years after the implementation of this program, Marco Polo-II program composed of 70 projects started to be implemented for the years 2007 to 2009. Budgets of these projects that are being carried out within this scope varies from 0.37 to 7.5 million. With these projects, 54 billion tone- $\mathrm{km}$ is aimed to be transported. Within the scope of the Marco Polo program, 22 projects with a budget of 66.34 million were completed in 2009 alone.

\section{Trans-European networks}

The basic program directly related with the improvement of the transport infrastructure in the EU is trans-European networks-transportation (TENs-T). The legal basis of $\mathrm{TENs}^{9}$ is the EU treaty. The idea of developing the TENs which occurred in consequence of the global developments in late 1980's developed together with the single market. The decision makers of the Community established a general framework which would encourage economic development and employment and include both the transport matters which they believed was directly associated with the establishment of the European single market and communications and energy. TENs generate comprehensive expectations such as social integration and it is aimed to develop a synergy through the relationship to be established between TENs and transport, energy and communications. The Commission released a study in 2007 which concentrated mostly on specific issues such as efficient use of free areas, reduction of costs and environment effect which provide added value (The Commission 2007c).

Within the framework of TEN, the $27 \mathrm{EU}$ member states succeeded to construct 5 million $\mathrm{km}$. blacktop roads $\left(61.6 \times 10^{3} \mathrm{~km}\right.$ of which are highways), $215.4 \times 10^{3}$ $\mathrm{km}$ railway $\left(107.4 \times 10^{3} \mathrm{~km}\right.$ of which are electric railways) and $41 \times 10^{3} \mathrm{~km}$ navigated inland waterways. Only in such a short period of six years, between 2000 and 2006, 859 billion Euros were spent within the scope of the program. In line with the success achieved it is envisaged to make an investment of 500 billion euros in addition to this amount. These mega projects which are well over the annual budget of the EU are funded by the credits provided from the European Investment Bank and by European Cohesion and Development Funds. The Commission opened its TEN-T policy to discussion with the green paper (Commission, 2009f) which was published in February 2009. Consequently, in May 2010 the Commission adopted the document which set out the principles that were developed until mid-2011 (The EU web site, 2012k).

\section{OTHER INITIATIVES OF LOGISTICS IN EUROPE}

\section{Logistic villages/bases/centers in Europe}

Logistic villages are the districts having easy access to the industries in the neighborhood through the transportation modes and enabling the joint operation of all the logistic activities and they are under the control of a certain authority. They began to be established in Europe, in 1960's, with the aim of coordinating the cross border activities of the logistic villages in a multinational universe, international organizations were founded.

\footnotetext{
${ }^{9}$ Chapter XV (Articles 154, 155 and 156) of the treaty establishing the EU.
} 


\section{Europlatforms}

Europlatforms (www.freight-village.com, 2012e) (whose members are the 60 enterprises, the founders of the Logistic Villages established in 1991) enable more than 1200 logistic enterprises to cooperate with the aim of protecting common interests. Similarly, FV 2000 is an organization established by 9 member countries (Denmark, Greece, France, Hungary, Italy, Luxembourg, Portuguese, Spain and Ukraine) for the effective operation of Logistic Villages.

\section{Intelligent transport systems in the EU}

These systems are aiming to create new service areas with the support of current technologies, and based on the view that in the recent years, computers, satellites, electronic equipment and sensors have increasingly integrated into the transportation field, the Community has begun to implement an initiative called intelligent transport systems (ITS) for the integration of intelligence and communication technologies into the field of transportation (The EU web site, 2012h).

\section{Road safety in the EU}

Nearly 40 thousand people died in accidents in the EU, just in 2008. The Commission exerts efforts (EU web site, $2012 \mathrm{j}$ ) to prevent the accidents leading to loss of life ${ }^{10}$ and also to great economic losses, by introducing tight measures with a number of legal regulations in many different fields.

\section{FUTURE OF THE EU TRANSPORTATION POLICIES}

In order to shape the future of transportation sector in the EU, the Commission released a new white book in 2011 (Commission 2011a, b). In that, a series of objectives to establish a competitive and source-oriented single European transportation market was put forward, some of which to be accomplished by 2020 , some by 2030 and some by 2050. In this context, in order to achieve zero $\mathrm{CO}_{2}$ emission within the logistic activities in cities, it is aimed to reduce the number of the conventional vehicles by half until 2030, and to withdraw these vehicles from operation in the city in 2050 . It is envisaged that the consumption of fuels with low carbon intensity in aviation and maritime sectors will reach the $40 \%$ target by 2050 . Until 2030, it is intended to use railway or maritime transportation for $30 \%$ of the load that is transported for more than $300 \mathrm{~km}$ through the land, and to raise this ratio

\footnotetext{
${ }^{10}$ In railway accident which is seen more safety died 83 people (apart from died of under the train workers) and 228 people died in airway accident. This 228 people died in the Air France Flight 447.
}

to $50 \%$ by 2050 . It is aimed to raise the present high speed rail network by three times until 2030 and to merge Europe's high speed rail network until 2050, and to enable most of middle distance travelers to use railway transportation. Moreover, it is aimed to raise the efficiency of market based activities by merging the routes that form the main airlines and railways (high speed rail lines if possible) with main sea routes (inland waterways if possible) until 2050. Among these, the modernization of the air traffic management infrastructure (SESAR), and the finalization of water transport management system (ERTMS, ITS, SSN/LRIT and RIS) and of European Global Navigation System (Galileo) by 2020 is the near future objective. In addition, it is aimed to establish an information, administration and payment system for multi-mode transportation in Europe in 2020. It is aimed to lower the number of mortal traffic accidents by half until 2020 and to none by 2050 . Thus, it is aimed to make the EU as the most secure region in all transportation modes. Lastly, the full application of the principle that envisaged the user to pay the cost, the elimination of government supports that hinder the entry of private capital to the sector, and the encouragement of investments in the transportation sector are targeted.

\section{CONCLUSION AND RECOMMENDATIONS}

The developments in the last five decades have increased the interest towards logistics all over the world. Despite this global trend, the EU has not developed a policy at the Community level, although common transport policy was formed at the same time when the Community was established. However, this does not mean that there has not been a logistic sector in Europe or logistics has been neglected; the Community members have used logistics in an apex size in the continent Europe. Six European countries among the first ten countries in the list of LPI included in the last version of the report published by the World Bank in 2012 supported this claim.

It has been seen that the strategic, social and political advantages of the Europe's geography have not been handled efficiently by the Community in terms of logistics. The fact that the ports such as Rotterdam, Antwerp and Amsterdam, which ranked at the highest levels in the world, recently leave their positions to Asian ports. Besides, traffic jams in main arterial highways, chronic delays in airways also point out that the European countries should develop more efficient policies and move in coordination. Another indicator for cooperation among the member states in logistic sector is the global crisis, which has a serious effect on the Euro zone.

The Community can neither solve the existing mainly economic and fiscal problems nor be successful in any of the existing common policies without developing efficient logistical strategies (EU Official Web Site (2012c). The EU cannot be successful in the competitive race with 
global rivals, mainly the USA and China, without common logistics strategies. As of 2012 the EU still tries to augment its transportation policy, but it is not the same for logistics. Taken into consideration that failures in logistics channels cost $1 \%$ of Europe's GDP and the logistics expenses provide almost $10 \%$ of all outgoings, (Commission, 2011b) the requirement for common logistic policy has become more definite and imperative for the Community. Therefore, the EU should transform its common transport policy to common logistics policy without delay. The new common logistics policy should cover not only transportation aspects but also some logistics matters such as warehousing, handling, distribution etc. Putting in to practice this proposal, which needs radical inner structural arrangements, would take time and not easy. First of all, convincing all the members to say yes will be a hassle. Even if all of the members say yes, some changes are required in Treaties and some arrangements in the budget in advance. Furthermore, some institutional changes, including the combination of the Commission, are the other entanglements in the EU, which is clumsy and inert bureaucratic actor. Consequently, there is no way for the EU, but the logistics.

\section{REFERENCES}

Amerini G (2010). Transport European port activity in 2009 hit by the general economic crisis, EuroStat Statistics in Focus. p. 65.

Arvis JF, Mustra MA, Ojala L, Shepherd B, Saslavsky D (2012). Connecting to Compete, Trade Logistics in the Global Economy, The Logistics Performance Index and Its Indicators, The International Bank for Reconstruction and Development/The World Bank.

Ballou RH (2004). Business Logistics/Supply Chain Management, $\left(5^{\text {th }}\right.$ Edition), Pearson Education International, Prentice Hall.

Bowersox DJ, Closs DJ (1996). Logistical Management: The Integrated Supply Chain Process, Singapore.

Commission of the European Communities (1992). White Paper on the future development of the common transport policy' (COM (92) 494 final, December. (1993). Council Regulation (EEC) No 95/93 of 18 January 1993 on common rules for the allocation of slots at Community airports (2001). White paper-'European transport policy for 2010: time to decide' [COM (2001)370], September.

Communication of the Commission to the Council (2006c). Freight Transport Logistics in Europe - the key to sustainable mobility, $\operatorname{COM}(2006) 336$ final, 28 June.

Communication of the Commission to the Council (2006d). A Mid-Term Review of the 2001 White Paper 'Keep Europe moving - sustainable mobility for our continent' [COM(2006)314].

Communication of the Commission to the Council (2007a). Communication from the Commission, The EU's freight transport agenda: Boosting the efficiency, integration and sustainability of freight transport in The Europe SEC (2007) 1351\} COM(2007) 606 final $\{$ SEC(2007) 1367\} Brussels.

Communication of the Commission to the Council (2007b). Communication from the Commission, Freight Transport Logistics Action Plan Impact Assessment, \{COM (2007) 607 final\}, Brussels, 2007.

Communication of the Commission to the Council (2007c). The Commission's Communication [COM (2007) 135 final] of 21 March 2007 to the Council and the European Parliament, entitled: TransEuropean Networks: Towards an integrated approach.

Communication of the Commission to the Council (2007d). Communication from the Commission - First progress Report on the implementation of the NAIADES Action Programme for the promotion of inland waterway transport.
Communication of the Commission to the Council (2007e). Communication from the Commission to the EP, the Council, the European Economic and Social Committee and the Committee of the Regions - Developing the international dimension of the Integrated Maritime Policy of the EU.

Communication of the Commission to the Council (2009a). Commission Decision of 17 December 2009 on minimum requirements for the data to be entered in the national electronic register of road transport undertakings (notified under document $C$ (2009) 9959) Text with EEA relevance.

Communication of the Commission to the Council (2009c). Commission Regulation (EC) No 1194/2009 of 30 November 2009 amending Regulation (EC) No 1702/2003 laying down implementing rules for the airworthiness and environmental certification of aircraft and related products, parts and appliances as well as for certification of design and production organizations.

Communication of the Commission to the Council (2009d). Communication from the Commission to the European Parliament, the Council, the European Economic and Social Committee and the Committee of the Regions - Strategic goals and recommendations for the EU's maritime transport policy until 2018.

Communication of the Commission to the Council (2009e). Commission staff working document, accompanying document to the report from the Commission to the Council and the European Parliament on monitoring development of the rail market $\{\operatorname{COM}(2009) 676$ final/2\}.

Communication of the Commission to the Council (2009f). Green Paper, TEN-T: A policy review- Towards a better integrated trans-European transport network at the service of the common transport policy, Consultation period: 04/02/2009-30/04/2009.

Communication of the Commission to the Council (2010a). Commission Regulation (EU) No 691/2010 of 29 July 2010 laying down a performance scheme for air navigation services and network functions and amending Regulation (EC) No 2096/2005 laying down common requirements for the provision of air navigation service.

Communication of the Commission to the Council (2010b). EU Energy and Transport in Figures, Statistical Pocketbook, European Union.

Communication of the Commission to the Council (2010c). Commission Staff Workıng Document, Impact assessment of the Single Aviation Market on Employment and Working Conditions, SEC(2010) 503 final Brussels.

Communication of the Commission to the Council (2011a). White Paper, on transport, Roadmap to a Single European transport areaTowards a competitive and Resource-Efficient Transport System, Brussels.

Communication of the Commission to the Council (2011b). Commission Staff Working Paper, Impact Assessment, Accompanying document to the White Paper "Roadmap to a Single European Transport Area Towards a competitive and resource efficient transport system SEC (2011) 359 final, SEC (2011) 391 final, Brussels, 28.3.2011.

Communication of the Commission to the Council (2012). Agriculture and Rural Development, History of CAP, Directorate-General for Agriculture and Rural. (the EU web site: http://ec.europa.eu/agriculture/cap-history/index_en.htm) Council of European Union;

Communication of the Commission to the Council (1992). Council Regulation (EEC) No 3577/92 of 7 December 1992 applying the principle of freedom to provide services to maritime transport within Member States (Maritime Cabotage).

Dekker S, Stevens H (2007). Maritime security in the European Unionempirical findings on financial implications for port facilities, Marit. Pol. Mgmt., October 34 (5).

EU Official Web Site (2012a). EU Policy Areas, (http://europa.eu/pol/index_en.htm).

EU Official Web Site (2012b). Mobility and Transport, (http://ec.europa.eu/transport/index_en.htm).

EU Official Web Site (2012c). Keeping Europe Moving, European Strategies, (http://ec.europa.eu/transport/index_en.htm).

EU Official Web Site (2012d). Transport, Maritime transport (http://ec.europa.eu/transport/maritime).

EU Official Web Site (2012e). FV2000, Freight Villages, (http://www.freight-village.com/projects.php?project=fv2000.

EU Official Web Site (2012f). Mobility and Transport, Roadmap to a 

$\begin{array}{llcc}\text { Single } & \text { European } & \text { Transport } & \text { Area, } \\ \text { (http://ec.europa.eu/transport/strategies/facts-and-figures/transport- }\end{array}$ matters/index_en.htm).

EU Official Web Site (2012g). Transport, Air-Internal Market, (http://ec.europa.eu/transport/air/index_en.htm).

EU Official Web Site (2012h). Transport, Intelligent Transport Systems, (What do we want to achieve?) (http://ec.europa.eu/transport/Intelligent Transport Systems).

EU Official Web Site (2012j). Transport, EU Road safety policy (http://ec.europa.eu/transport).

EU Official Web Site (2012k). Transport, TEN-T / Transport infrastructure (http://ec.europa.eu/transport).

EU Official Web Site (2012l). Taxation and Custom Union, A few facts on EU customs, EU Customs strategy (http://ec.europa.eu/taxation_customs).

EU Official Web Site $(2012 \mathrm{~m})$. Transport, Inland waterway transport (http://ec.europa.eu/transport/inland).

EU Official Web Site (2012n). Transport, Marco Polo, Marco Polo in action (What do we want to achieve?) (http://ec.europa.eu/transport).

EU Facts (2012). (http://www.civitas.org.uk/eufacts/FSPOL/EC7.htm).

Europlatforms (2012). Freight Villages, (www.freight-village.com).

Eyefortransport (2012). The European,3PL Summit, 14-15 October, London (www.eyefortransport.com/3pl/).

Farantouris N (2012). Port Infrastructure and State Aids: In Search of a Coherent EU Policy, European State Aid, Quarterly.

Ghiani G, Gilbert L, Roberto M (2004). Introduction to Logistics Systems Planning and Control, John Wiley Sons Ltd., UK.

Gleave SD (2009). D3 - Final Report for Commission, Evaluation of the CTP of the EU from 2000 to 2008 and analysis of the evolution and structure of the European transport sector in the context of the longterm development of the CTP, August.

Koldemir B, Özen S, Akten N (2007). Problems of transport systems serving for Europe-Middle East trades within the framework of EU transport policy and solution proposals. J. Black Sea/Mediterr. Environ. 13:261-279.
Kuşçu S (2011). The EU Transportation Policy and its Reflection to Turkey. Acad. Perspect. 5:9

Meyer-Rühle O, Sigrun B, Anne G (2008). Final Report Statistical Coverage and Economic Analysis of the Logistics Sector in the EU (SEALS) Prepared for the European Commission, DG Energy and Transport, ProgTrans AG: SEALS - Final Report, December.

Murphy PR, Wood D (2004). Contemporary Logistics, Pearson Education International, Prentice Hall.

Paixaäo AC, Marlow PB (2001). A review of the European Union Shipping Policy. Maritime Policy Manag. 28:2.

Šakalys A, Palšaitis R (2006). Development of Intermodal Transport in New European Union States Transport Research Institute, Vilnius Gediminas Technical University, Lithuania.

Schmidt M, Giorgi L (2001). Successes, Failures and Prospects for the Common Transport Policy', Innovation. Eur. J. Soc. Sci. Res. 14:4.

Stock JR, Douglas LM (2001). Strategic Logistics Management, Fourth Edition, McGraw Hill.

Solecka K (2011). Integration of Public Transport in Polish and EU Documents and Examples of Solutions for Integratıon of Publıc Transport in Poland and in the World. 6:4.

Treaties (1957). The Treaty of Rome, Title IV Transport, 25 March 1957.

Treaties (1992). Treaty on European Union (Treaty on Maastricht) Official Journal OJ C 191 of 29.7.1992.

Wolf W (2006). Transport Policy in the European Union. Debatte 14:2.

${ }^{\mathrm{i}}$ ECC (European Economic Community) from 1957 to 1960; EC (European Communities) from 1960 to 1992, EU (European Union) from 1992 up to now. EU or Community hereafter for all. 